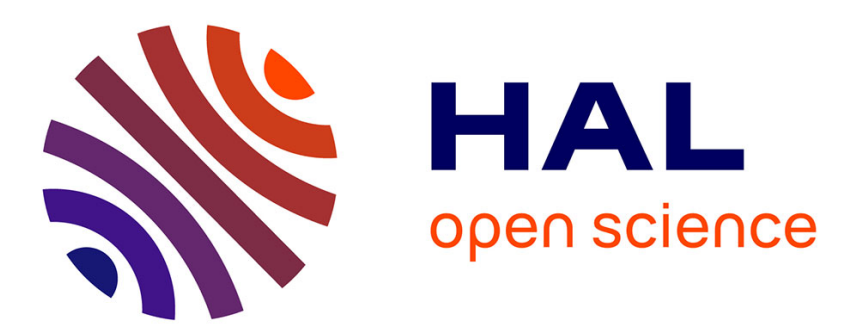

\title{
Growth by the heat exchanger method of NaBiW2O8 and Na5B2P3O13 crystals
}

H. Rahab, D. Ouadjaout, A. Manseri, Jean-Pierre Chaminade, Oudomsack Viraphong

\section{- To cite this version:}

H. Rahab, D. Ouadjaout, A. Manseri, Jean-Pierre Chaminade, Oudomsack Viraphong. Growth by the heat exchanger method of NaBiW2O8 and Na5B2P3O13 crystals. Journal of Crystal Growth, 2007, 303 (2), pp.629-631. 10.1016/j.jcrysgro.2006.12.059 . hal-00144341

\section{HAL Id: hal-00144341 https://hal.science/hal-00144341}

Submitted on 4 Jun 2021

HAL is a multi-disciplinary open access archive for the deposit and dissemination of scientific research documents, whether they are published or not. The documents may come from teaching and research institutions in France or abroad, or from public or private research centers.
L'archive ouverte pluridisciplinaire HAL, est destinée au dépôt et à la diffusion de documents scientifiques de niveau recherche, publiés ou non, émanant des établissements d'enseignement et de recherche français ou étrangers, des laboratoires publics ou privés. 


\title{
Growth by the heat exchanger method of $\mathrm{NaBiW}_{2} \mathrm{O}_{8}$ and $\mathrm{Na}_{5} \mathrm{~B}_{2} \mathrm{P}_{3} \mathrm{O}_{13}$ crystals
}

\author{
H. Rahab ${ }^{\mathrm{a}}$, D. Ouadjaout ${ }^{\mathrm{a}}$, A. Manseri ${ }^{\mathrm{a}}$, O. Viraphong ${ }^{\mathrm{b}}$, J.P. Chaminade ${ }^{\mathrm{b}, *}$ \\ ${ }^{a}$ UDTS, 2, Bd Frantz Fanon, BP 140, Alger 7 merveilles Algiers 16200, Algeria \\ ${ }^{\mathrm{b}}$ ICMCB CNRS, 87 Avenue du Dr. Albert Schweitzer, Université Bordeaux1, 33608 Pessac cedex, France
}

\begin{abstract}
In this paper, we present the results of our attempt to grow $\mathrm{NaBiW}_{2} \mathrm{O}_{8}$ (NBW) and $\mathrm{Na}_{5} \mathrm{~B}_{2} \mathrm{P}_{3} \mathrm{O}_{13}$ (NBP) crystals by the heat exchanger method (HEM). This method is slightly different from the Bridgman technique: the crucible is kept fixed in the setup and the center of the crucible bottom is cooled by a variable helium gas flow. It allows very good control of the growth rate and minimizes parasitic crystallization at the crucible walls. First experiments for growing these two materials by the HEM technique have shown very promising results with single crystal sizes of few cubic centimetres.
\end{abstract}

Keywords: A1. Growth from melt; A1. HEM; A2. Phosphates; A2. Tungstates; B1. Non linear optics materials; B1. Scintillator materials

\section{Introduction}

Heat exchanger method (HEM) is a simple directional solidification technique, which has been adapted for the growth of large single crystals [1]. Its specific feature is a helium-gas-cooled heat exchanger in contact with the bottom of the crucible. At the beginning of the growth, the charge is heated at a low gas flow until a seed crystal, which is placed on the base of the crucible is partially molten. Then the gas flow is increased and the crystallization starts from the seed-in to the melt. Since the temperature of the crucible walls remains unchanged, the growing crystal cannot reach them until the end of the growth process, which prevents secondary nucleation and ensures low strain in the crystal. At the end of the growth process, the heating power is reduced and crystal comes into contact with the crucible walls. A distinguishing feature of HEM, as compared to other crystal growth processes, is that there are no moving parts in the system and that the solid-liquid interface is submerged beneath the surface of the melt. Under these conditions, thermal

\footnotetext{
*Corresponding author. Tel.: + 33540006562 ; fax: +33540002761 .

E mail address: chamin@icmcb bordeaux.cnrs.fr (J.P. Chaminade).
}

and mechanical perturbations are damped out resulting in uniform temperature gradients at the interface. This promotes uniform growth, which produces high crystal perfection and chemical homogeneity [2]. Moreover, HEM allows independent controlling of liquid and solid temperature gradients during the growth cycle since the temperature gradients in the liquid are only affected by the furnace temperature and the thermal conductivity of the liquid, whereas the temperature gradients in the solid depend on the heat exchanger temperature and the thermal conductivity of the solid. In the past, HEM has been mainly utilized for the growth of large multi-crystalline silicon ingots and sapphire crystals [3,4]. Recently, it was tested to get $\mathrm{NaMgF}_{3}$ [5] and high-melting oxide crystals [6]. In this paper, we report the details of our attempts to grow $\mathrm{NaBiW}_{2} \mathrm{O}_{8}(\mathrm{NBW})$ and $\mathrm{Na}_{5} \mathrm{~B}_{2} \mathrm{P}_{3} \mathrm{O}_{13}$ (NBP) crystals by HEM method.

\section{Crystal growth procedure}

\subsection{Apparatus for crystal growth by HEM}

Our home-made HEM apparatus consists of a watercooled chamber containing a Kanthal-super resistance 
heater. A high-temperature heat exchanger, which is a closed-end inconel tube, is cooled by a controlled flow of helium gas. The heat exchanger is introduced from the bottom of the furnace into a hot zone. A schematic of the HEM furnace is shown in Fig. 1. A crucible, loaded with the charge, is placed in the hot zone on the top of the heat exchanger. During crystal growth, the chamber can be under vacuum or backfilled with an inert gas for controlled atmosphere processing or air atmosphere. The resistance heater supplies heat for the melt of the charge. To initiate growth, a seed can be placed at the bottom of the crucible, underneath the charge; in this case, a minimal coolant gas flow through the heat exchanger during the melt of the charge prevents the seed from melting. Both heat exchanger and furnace temperatures are regulated and programmed by Eurotherm-902P controllers, using $\mathrm{Pt} /$ $\mathrm{Pt}-10 \% \mathrm{Rh}$ thermocouples.

The process is fully automated by using Labview software developed at ICMCB.

Once the charge is melted, growth is initiated by increasing helium flow, thus decreasing heat exchanger temperature. Complete solidification is attained by progressively lowering the heat exchanger temperature; the furnace temperature can also be simultaneously decreased below the melting point, particularly when the heat exchanger has attained its extraction limit although solidification is not yet achieved.

\subsection{Crystal growth of $N B W$ and $N B P$}

Sodium-bismuth tungstate $\left(\mathrm{NaBiW}_{2} \mathrm{O}_{8} ; \mathrm{NBW}\right)$ is a new material of high density $\left(7.57 \mathrm{~g} / \mathrm{cm}^{3}\right)$ that can be used as

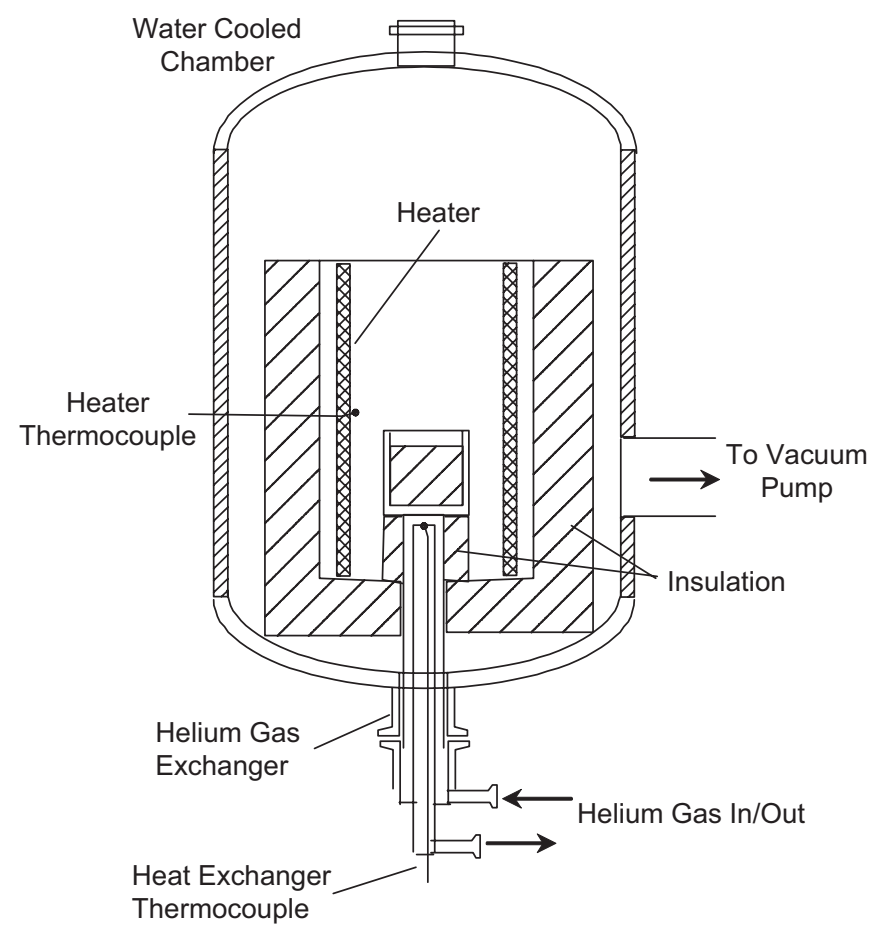

Fig. 1. Schematic drawing of the HEM apparatus [4]. scintillator crystal. It has the scheelite $\left(\mathrm{CaWO}_{4}\right)$ structure of the space group I4. The unit cell parameters are: $a=b=5.28 \AA, c=11.52 \AA$. NBW melts congruently at $935 \pm 3{ }^{\circ} \mathrm{C}$. It has been generally grown by the Czochralski method, both non-doped and doped with lanthanide elements [7]. Sodium-phosphate $\left(\mathrm{Na}_{5} \mathrm{~B}_{2} \mathrm{P}_{3} \mathrm{O}_{13} ; \mathrm{NBP}\right)$ crystallizes in the non-centro-symmetric monoclinic system, space group $\mathrm{C} 2$. The unit cell parameters are: $a=6.71 \AA$, $b=11.61 \AA$ A $, c=7.68 \AA, \beta=115.2^{\circ}$. NBP crystal exhibits an optical second harmonic generation effect about the same as that of KDP $\left(\mathrm{KH}_{2} \mathrm{PO}_{4}\right)$ and a wide transparency range. It melts congruently at $787^{\circ} \mathrm{C}$, and has been recently grown by Czochralski method; some of its properties were investigated [8]. As a promising non-linear optical material, the crystal growth and properties of this new material are of interest.

NBW and NBP compounds were prepared by classical solid-state reaction. Regarding $\mathrm{NBW}, \mathrm{Na}_{2} \mathrm{CO}_{3}, \mathrm{Bi}_{2} \mathrm{O}_{3}$ and $\mathrm{WO}_{3}$ of $99.99 \%$-up purity were used as starting materials. They are weighed according to the 1:1:4 molar ratios. The mixed powder was first heated at $700^{\circ} \mathrm{C}$ for $10 \mathrm{~h}$ to decompose the carbonate. After that, it was heated up to $860^{\circ} \mathrm{C}$ and kept at this temperature for $24 \mathrm{~h}$ so that the reaction is completed. To synthesize NBP, commercially available $\mathrm{Na}_{2} \mathrm{CO}_{3}, \mathrm{H}_{3} \mathrm{BO}_{3}$ and $\mathrm{NH}_{4} \mathrm{H}_{2} \mathrm{PO}_{4}$ of $99.99 \%$-up purity are used as starting materials. They are weighed according to the 2.5:2:3 molar ratios. The mixed powder was pre-heated at $300{ }^{\circ} \mathrm{C}$ for $12 \mathrm{~h}$ to remove water and $700{ }^{\circ} \mathrm{C}$ for $12 \mathrm{~h}$ to decompose the carbonate. Then, temperature was increased to $750^{\circ} \mathrm{C}$ and kept for $24 \mathrm{~h}$ to complete the reaction. X-ray diffraction analyses have shown that for the two cases, the obtained polycrystalline powder was in single phase. About $70 \mathrm{~g}$ of the polycrystalline powder obtained was introduced into a Pt crucible of conical form $(50 \mathrm{~mm}$ height, lower diameter $=25 \mathrm{~mm}$ and upper diameter $=44 \mathrm{~mm}$ ) and placed on top of the inconel heat exchanger. There is no lid on top of the crucible. The growth period is usually 3 days, starting from seeding of the prepared melt.

First experiments for growing the two materials (NBP, NBW) with the HEM technique have been conducted, initially without using a seed crystal, then with an oriented seed positioned in the bottom of the crucible. Without using a seed crystal, polycrystalline ingots were obtained for the two materials with grains oriented along the thermal gradient, and sizes approaching the centimeter (Fig. 2a-c). The furnace is closed on the top; one leaves a small opening in the form of groove for the camera and visual observation purposes. A thermocouple gained with a Pt tube is placed just on the surface touching the liquid (Fig. 2). Based on these preliminary attempts, the heating power for the melting and solidification cycles was adjusted. In order to optimize the growth rate, cooling rates were varied and applied both to the heater and the heat exchanger contact point.

A second series of experiments were conducted using an oriented seed crystal, with the size of $11 \times 7 \times 5 \mathrm{~mm}^{3}$, 



Fig. 2. Stages of NBP crystal growth by HEM: (a) melt in, (b) appearance of the first seeds and (c) growth of seeds.

obtained by Czochralski pulling. The seed rested in the bottom of the crucible, growth being performed along the $b$-axis direction. Parameters involved in the experiments are: the heater temperature $\left(T_{\mathrm{f}}\right)$, the temperature of the heat exchanger-crucible bottom contact point $\left(T_{\mathrm{d}}\right)$, also their variation rates (the latter follows the front solidification progress). To illustrate the evolution of the process parameters during crystal growth, we consider the case of NBP. The charge is heated to $840^{\circ} \mathrm{C}\left(53^{\circ} \mathrm{C}\right.$ above the melting point of NBP) to ensure it is completely melted. Then $T_{\mathrm{f}}$ is reduced to $821{ }^{\circ} \mathrm{C}$. Growth was initiated with $T_{\mathrm{d}}=726^{\circ} \mathrm{C}$ (temperature at which the first germ appears) and sustained by reducing both the heat exchanger and the furnace temperatures by 1 and $0.3^{\circ} \mathrm{C} / \mathrm{h}$, respectively, over $15 \mathrm{~h}$. Then, solidification is completed by applying a decreasing temperature program of $1.5^{\circ} \mathrm{C} / \mathrm{h}$ for the furnace, and $9{ }^{\circ} \mathrm{C} / \mathrm{h}$ for the heat exchanger. In this case, the growth rate was assessed to be $3 \mathrm{~mm} / \mathrm{h}$. This determined growth rate is a mean value measured between the appearance of the first germ and the disappearance of the last drops of liquid on the surface. The thickness is measured once the solid is withdrawn.

The best results up to now are shown in Fig. 3. Visible part of the crystal shows many inclusions in the form of gas bubbles. This shows that the applied gas cooling rate was not able to draw enough heat from the system to fully crystallize the melt. The still molten top zone of the melt crystallized from the surface down when the heating power was reduced at the end of the growth process.

\section{Conclusion}

The HEM was, for the first time, used to grow NBP and NBW crystals. First experiments have shown very promising results with single-crystal sizes of several cubic centimetres, even without using a seed crystal. In the
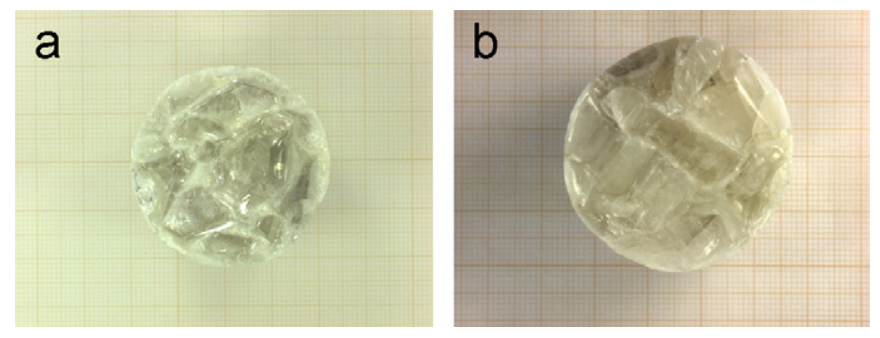

Fig. 3. De moulded NBP blocks: (a) $V\left(T_{\mathrm{f}}\right)=1{ }^{\circ} \mathrm{C} / \mathrm{h}, V\left(T_{\mathrm{d}}\right)=3{ }^{\circ} \mathrm{C} / \mathrm{h}$ then $15^{\circ} \mathrm{C} / \mathrm{h}$ and (b) $V\left(T_{\mathrm{f}}\right)=0.3{ }^{\circ} \mathrm{C} / \mathrm{h}, V\left(T_{\mathrm{d}}\right)=1{ }^{\circ} \mathrm{C} / \mathrm{h}$ then $15^{\circ} \mathrm{C} / \mathrm{h}$.

future, the use of monocrystalline seeds, obtained by the Czochralski method, should enable us to grow largevolume high-quality crystals of these two promising materials.

\section{Acknowledgment}

This work has been supported by CMEP (cooperation algéro-française) under project number 01-MDU-519.

\section{References}

[1] F. Schmid, D. Viechnicki, J. Am. Ceram. Soc. 53 (9) (1970) 528.

[2] Web site: 〈http://www.crystalsystems.com/〉.

[3] F. Schmid, US Patent 3,898,051 (1975).

[4] C.P. Khattak, F. Schmid, J. Crystal Growth 225 (2001) 572.

[5] A. Oçafrain, J. P. Chaminade, O. Viraphong, R. Cavagnat, M. Couzi, M. Pouchard, J. Crystal Growth 166 (1996) 414.

[6] V. Peters, A. Bolz, K. Petermann, G. Huber, J. Crystal Growth 237239 (2002) 879.

[7] V. Volkov, C. Zaldo, J. Crystal Growth 206 (1999) 60.

[8] Z. Li, Y. Wu, P. Fu, S. Pan, Z. Lin, C. Chen, J. Crystal Growth 255 (2003) 119. 